\title{
Religion and the Problem of Rationality: Insights from Akan Religious Thought
}

\author{
H.M. Majeed \\ Department of Philosophy and Classics \\ University of Ghana \\ mmajeed50@yahoo.com OR mmajeed@ug.edu.gh
}

DOI: http://dx.doi.org/10.4314/tp.v6i2.2

Thought and Practice: A Journal of the Philosophical Association of Kenya (PAK)

New Series, Vol.6 No.2, December 2014, pp.1-22

thoughtandpractice@gmail.com

http://ajol.info/index.php/tp/index

ISSN: 2076-7714 


\begin{abstract}
Arguments against the practice of religion and, in general, against belief in metaphysical entities, have been made in different cultures and at different times in human history. This article, however, does not offer a historical outline of such arguments. Rather, it reflects on some contemporary remarks made, especially in Western thought, against religion. It illustrates how a correct understanding of Traditional Akan Religion renders untrue claims that seek to dismiss religion on the grounds of irrationality. Utilising philosophical reflection, it shows how rational belief in a Traditional African Religion such as the Akan one is.
\end{abstract}

\title{
Key Words
}

Rationality, revelation, logical positivism, predestination, free will, Akan religion, African religion

\section{Introduction}

In some Western conceptions, religion is deemed to be devoid of any rational basis. Such conceptions appear to hinge on the way religion (specifically Judeo-Christianity) is practised in Western culture. This religion, which is the dominant one in the West, is viewed as having originated from a God whose existence cannot be scientifically proved, and who "revealed" Himself to humans as an object of worship; and, that the principles of that religion were brought to humankind through an intermediary (Jesus Christ). Humankind, in this case, did not find - or better still, did not rationally discover - religion, but was given religion. Religion, then, is generally portrayed by anti-religionists as irrational. Nevertheless, this article seeks to show that by 'irrationality' critics often have in mind the idea that religious beliefs have one or more of the following features:

- They are unscientific.

- Even when they are said to be based on 'reason' (as in natural religion), they cannot lead to salvation.

- The language with which they are expressed is meaningless. 
- They are often inconsistent.

I argue against the rejection of religion on the basis of the four points listed above, and explain how some beliefs held in Traditional Akan Religion ${ }^{1}$ makes my position tenable. I show how the Akan perspective differs from the views of specific Western scholars, and how it withstands their criticisms.

\section{On the Nature and Origin of Traditional Akan Religion}

The issue of what the true nature of Traditional African Religion is - that is, whether its moral values or the religion itself has a human or supernatural origin - has for a long time been a subject of debate among scholars. ${ }^{2}$ With regard to the origin of Traditional African Religion, Akan religion included, one view is that its origin is implicit in its naturalness. The opposite view is that the supernatural origin of the religion is implied by its revealed nature. In recent times, Pius Abioje and Kwame Gyekye have expressed these two divergent views. While Abioje holds that Traditional African Religion is not natural but is revealed (Abioje 2007, 149-150), Gyekye suggests that Akan thinkers postulate that Akan religion has a human origin, devoid of any divine revelation (Gyekye 1996, 5). Indeed, my own studies and knowledge of the Akan culture corroborates Gyekye's position. The heavy concentration of Akan religion on the usefulness of religion to human life on earth, as well as the absence of oral or written history about God's expression of His own will and identity to humans, constitute ample evidence that the religion is not revealed. The significance of all this is that Abioje's generalized assertion about Africa is quite mistaken.

However, Traditional Akan Religion is replete with beliefs that are related to the supernatural. There are key Akan beliefs concerning entities such as God (Nyame), the deities

\footnotetext{
${ }^{1}$ Throughout this work, I will refer to indigenous Akan religion as "Traditional Akan Religion", not "traditional Akan religion". This is to ensure that the name of the religion is written in a manner consistent with the way other religions are written. When the names of such religions are spelt, the initial capital letter is used, and I have done the same for this religion because its status is similar to the others and, as Soyinka (2004) would agree, deserves equal treatment. When, from my observations on Akan religion I speak occasionally of Traditional African Religion, I do not imply that no differences exist in terms of religious belief and practice among African peoples; rather, I only endorse the well-known fact that they share a lot in common - especially in terms of the points discussed in this article - to warrant some sort of general description.

${ }^{2}$ Find debate on the origin of African moral values in Idowu 1962, 146; Opoku 1978, 152, 153; Quarcoopome1987, 162-163; Wiredu 1980, 5-6.
} 


\section{H.M. Majeed}

(abosom) and, to use Mbiti's expression, the living-dead (nananom nsamanfo). There is also the moral belief that there are consequences for human actions on earth, with good actions attracting good consequences and bad actions attracting bad consequences. Nevertheless, since these consequences are very often expected to be felt in the practical lives of humans here on earth, it would be inappropriate to assume that Traditional Akan Religion is entirely supernaturalistic.

Traditional Akan Religion, from the foregoing, appears to have a human origin, having been rationally developed for the benefit of humankind. Yet some philosophers, especially Western ones, have argued against the rationality of all religions. In this work, I seek to show that such criticisms do not apply to Traditional Akan Religion; and since the criticisms are made from the perspective of Christianity, responding to them naturally requires that I contrast Traditional Akan beliefs with Christian ones at various points in the discussion.

\section{On the Meaning of 'Religious Beliefs'}

Every religious tradition is founded on a set of core beliefs that are often about the supernatural realm. In the understanding of Wittgenstein, a religious belief is not an 'opinion' of its holder but a sort of 'dogma or faith'; and that, in matters concerning religious belief or, generally, in religious discourse, '[w]e don't talk about hypothesis, or about high probability. Nor about knowing' (Wittgenstein 1966, 3). This seems to suggest that Wittgenstein would consider statements that express religious beliefs neither as scientific conclusions (or confirmable truths), nor as claims about things that can be known. Thus belief in such things as resurrection and the last judgement - both Christian beliefs which he pays significant attention to in the work cited above - as well as indigenous Akan belief in the existence and religious significance of the living-dead to the community would be seen by him as mere dogmas. Yet a dogma is usually understood as a religious doctrine that is proclaimed as true without 'proof'. ${ }^{3}$ I acknowledge, however, that Wittgenstein's critique of the idea of taking something to be true without knowing if it indeed is, is made in connection with the Christian religion within whose context he appears to undertake his reflections, but not with a religion such as the Traditional Akan one; and by so doing, he seems to imply that the Christian beliefs mentioned above cannot be proved by their holders themselves to be true in the

${ }^{3}$ Later in the essay, the idea that strict 'proof' ensures rationality is questioned. 
manner suggested by him. By virtue of that criterion, Wittgenstein's remark could nonetheless apply to Traditional Akan Religion. Another word used by Wittgenstein to describe religious belief is 'faith'. However, since faith could be understood as a religious belief system, it is, I think, quite an appropriate term in this context.

Wittgenstein's analysis of religious belief is interesting. For instance, although he claims that he does not believe in resurrection, he maintains that he does not thereby contradict the person who does. The claims 'I do not believe in a future resurrection of the human being' and 'I do believe in a future resurrection of the human being' are, according to him, not contradictory. This, for Wittgenstein, is because he is neither suggesting the impossibility of the resurrection nor claiming that the believer has no reason for supposing it: all he means is that he is not sure about the resurrection (Wittgenstein 1966, 1). This indicates that the word 'believe' as used by Wittgenstein here implies some sort of assurance or certainty about having knowledge, although in some cases he suggests (by it) to have 'faith' or 'dogma'. For instance, he remarks of belief in the last judgement: 'how are we to know whether to say he [the religious practitioner] believes [that is, knows or is certain that] this will happen or not? Asking him is not enough. He will probably say he has proof. But he has what you might call an unshakable belief [faith]' (Wittgenstein 1966, 1; words in square brackets added). However, Wittgenstein's restriction of the distinct senses of 'believe' to the two parties inadvertently calls into question the demand often made by critics of religion that the religious practitioner must know, that is, he/she must know something about his or her beliefs for them to be rational; for, by Wittgenstein's own argument, faith or dogma is not knowledge.

Furthermore, Wittgenstein's point about the absence of contradiction in the two statements concerning belief in resurrection appears to serve a strategic end for him: he seems to stress this point for logical reasons; for if a religious practitioner proclaims 'I believe in a future resurrection of the human being' and Wittgenstein states 'I do not believe in a future resurrection of the human being', and these statements are understood respectively as 'I have faith that there is human resurrection' and 'I have faith that there is no human resurrection', Wittgenstein would not be able to criticize entirely the one he is opposing because, logically, both of them would have to first acknowledge that the idea of 'resurrection' is meaningful before affirming or denying its existence. Nevertheless, this clever move also lands Wittgenstein in some difficulty because by claiming that neither he nor the religious 


\section{H.M. Majeed}

practitioner is certain about the truth of religious beliefs, he (Wittgenstein) is still not better placed - in the acquisition of knowledge - than the religious practitioner from whom he tries to distinguish himself.

The question still remains whether or not religious belief can be rational. However, before this issue is discussed further, an important distinction needs to be made, namely, the distinction between supernaturalism, a term I have already used a number of times in this article, and superstition.

By 'supernaturalism' I mean the view that there is a reality beyond the natural world, where by 'natural world' is meant the physical realm - one which can be investigated using scientific means. In its primal sense therefore, supernaturalism is an orientation or a disposition and, in some sense, a worldview. It is tempting to see this orientation or belief as simply religious since, with it, humans are able to postulate the existence of God, deities, the living-dead and all sorts of metaphysical entities that are either worshipped or revered or both. However, not all postulations of the supernatural are religious. Indeed, it is possible to argue that a person has a spirit without placing any religious significance on it. Thus although claims about all supernatural entities or events are neither scientifically testable nor provable, the non-religious nature of some supernatural (human) experiences cannot be ignored. In sum, the supernatural includes any experience, action or event that cannot be explained by what are referred to as the laws of science.

Superstition, on the other hand, is any belief that is not based on knowledge or reason. By definition then, superstition is irrational and is rejected by science not only because anything dependent on it is incapable of empirical observation, but also because it lacks rational justification. This is where it is distinct from supernaturalism: while superstition is always irrational, supernaturalism could be rational. It is consistent with the preceding statement to hold that a belief in the supernatural could become superstitious, especially if nothing that resembles good argument could be offered for that belief. It is for this reason that Kwasi Wiredu $(1980,42)$ described some traditional African beliefs as "no better than superstition". It is therefore possible for some beliefs, practices and arguments for the supernatural to be unintelligible, or even unhelpful to humans. For instance, while belief in a metaphysical deity who is infinite and finite is logically flawed, the view that people should pursue the will of a transempirical deity even when it leads to or encourages oppression of our neighbours would 
be inhuman. Thus, this article's argument for the rationality of supernaturalism cannot connote a blanket justification of anything supernatural.

\section{On the Alleged Irrationality of Religious Beliefs}

Various arguments have been advanced in support of the view that religion is irrational. Four of such arguments are examined in this section, namely, science and religious belief, reason and salvation, meaninglessness of religious language, and inconsistencies in religious beliefs.

\section{Science and Religious Belief}

Lara Buchak $(2012,18)$, in an attempt to establish the sense in which the rationality of faith can most appropriately be determined, makes a distinction between epistemic and practical rationality. Epistemic rationality, in her view, is when 'you proportion your belief to the evidence and your beliefs must be coherent (in other words, your credences must obey the probability calculus)' - that is to say, 'degrees of probability obey the probability calculus' when '[you] update [your] beliefs by conditionalizing on new evidence.' On the other hand, practical rationality involves 'selecting the means to achieving one's ends' such that the means that help you most in achieving those ends are the most rational choices to make (Buchak 2012, 18). Buchak affirms, on the grounds of practical utility, that faith can be rational.

However, Buchak's position stands in sharp contrast with the views of many Western philosophers who completely reject religious beliefs in various ways. For instance, Wittgenstein rejects belief in God for not yielding to objective criteria and for not being something he could be sure about (Wittgenstein 1966, 1), while other philosophers such as Daniel Dennett (2008) and Richard Dawkins (2007) outrightly deny the existence of God. In a manner consistent with the position of Dennett and Dawkins, Robin Horton maintains that faith, and for that matter belief in God, is irrational, stressing that it can in no way be supported by reason (Horton 1960, 222). In fact, Horton and his counterparts criticize religious beliefs for not meeting the scientific criterion of rationality. It is also worth noting that Wittgenstein does not only endorse the scientific criterion of testing beliefs, but also asserts that the word 'God' does not correspond to any mental 'picture' (or thought) in his mind, as he cannot also confirm any 'evidence' produced by the practitioner of religion: 


\section{H.M. Majeed}

If I even vaguely remember what I was taught about God, I may say: 'Whatever believing God may be, it can't be believing in something we can test, or find means of testing.' You may say: 'This is nonsense, because people say they believe on religious experiences.' I would say: 'The mere fact that someone says they believe on evidence doesn't tell me enough for me to be able to say now whether I can say of a sentence "God exists" that your evidence is unsatisfactory or insufficient' (Wittgenstein 1966, 5).

Before I continue with the issue of testing (or science), it is important that I make a comment on Wittgenstein's statement that people 'believe on religious experience'. In Traditional Akan Religion, while religious experience cannot be said not to exist, religious experience (in many respects) is not really the reason why one postulates the existence of God. One does not 'see' a being and conclude that it is God or 'hear' a voice and conclude that it is God's, nor is it held in Akan thought that God is experienced in nature. It is quite odd for an Akan to say m'ahu Nyame (I have seen God) or Nyame aka akyere me se ... (God has told me that ...). Religious experience in the manner just described, however, does apply to some other spiritual entities such as the deities (abosom) and the living-dead (nananom nsamanfo). Traditional Akan Religion is naturalistic, as noted by Gyekye (1996, 5). This means that the originators of this religion engaged in some reflection about the universe, the things which they believed were contained in the universe (both physical and spiritual), the workings and the relations among the said things before coming up with the idea of God (Nyame). Nyame is conceived of as a being who is completely supernatural (sunsum) and a creator (bōrebōre). $\mathrm{He}$ is not regarded as part of his creation, that is, he is not considered to be part of nature. Yet the contrary is sometimes intended when it is claimed in some non-Akan religions that God is experienced in nature.

Traditional Akan Religion, and for that matter African religion as a whole, is essentially oriented toward enhancing the well-being of humankind. To this end, it is as effective as the human being feels it is. This implies that religious beliefs (such as belief in God) are intended to be practically useful. The deities, it is believed, are intermediaries between God and human beings, bringing to humankind goods from God. According to Gyekye (1996, 16), practitioners of African religion have in the past deserted some deities for not meeting the needs of the people. Non-performance could still cause deities to suffer the same fate today; and the seriousness with which lack of utility is confronted suggests, at the least, that religious belief could be the most efficacious way of solving some of the problems faced by human beings. In this sense, religious belief could be rational, especially if 'rational' here is 
understood in line with Buchak's position on practical rationality - which is that one chooses the best means to achieving one's ends.

Let us then return to the issue of science and religion. As earlier noted, from the arguments of some Western philosophers above, in religious traditions such as Christianity where revelation is the main source of religious beliefs - about God, resurrection of humans, the last day, heaven and hell, among others - the rejection of those beliefs for their apparent lack of rational basis is partly done on the assumption that one cannot rely on science (and thus one's own rational faculty) to come up with these beliefs and also to come to a firm conclusion that they are true; ${ }^{4}$ and, that in the face of what could be regarded as 'inconclusive evidence', reason requires that one rejects such beliefs. Nevertheless, is it always the case that certainty is required for beliefs or statements expressing beliefs to be rational? If this question could be answered in the affirmative, many scientific assumptions (and, a bit more generally, science itself) would not be rational. This is due to the fact that it is a virtue of science that it does not regard its claims to constitute absolute knowledge. I do not suggest that there is no truth in science; instead, my point is that beliefs and assumptions lead to different degrees of certainty, so that neither science nor religion guarantees certainty. ${ }^{5}$

The foregoing does not imply that the question of uncertainty associated with religious claims does not arise in Traditional Akan Religion in which revelation is absent. After all, it has supernatural beliefs which science cannot investigate. Philosophers of science would most likely reject Akan religious beliefs in the living-dead and the deities as lacking 'rational' (scientific) basis. Nevertheless, I have explained above how rational Traditional Akan Religion is, being a natural religion, with its beliefs (such as belief in God) having a rational basis. This challenge to the views of the critic is enhanced by Buchak's argument for the practical rationality of faith:

..., whether faith is rational depends on the kind of world we are in. Faith will be rational to the extent that evidence isn't ordinarily very conclusive, or to the extent that our decisions usually do have postponement costs. We won't be able to vindicate the claim that faith is rational regardless of the circumstances. But we can explain why having faith is rational in certain

\footnotetext{
${ }^{4}$ Jarvie and Agassi (1979, 173-5) share this view.

${ }^{5}$ Robert Winston (2008) holds a similar view. Further arguments against testing (or science) are made shortly in my discussion of Logical Positivism.
} 
worlds, perhaps worlds like ours ... Individuals who lack faith because they insist on gathering all of the available evidence before making a decision stand to miss out on opportunities that could greatly benefit them (Buchak 2012, $35)$.

Thus despite all its uncertainties, religious faith may not only be rational to have, but could also be profitable to humankind, just as we earlier observed about Traditional Akan Religion.

Indeed, as mentioned earlier (and Buchak would agree), religious beliefs can be irrationally used. There are times when religious beliefs are put to bad use. In recent African history, terrorism and violent conflicts are vices that beg to be mentioned. Perpetrators of the violent attacks in Northern Uganda claim to be inspired by Christian teachings, while planners and executors of the Nairobi Westgate Mall attack in 2013, and the ongoing terrorist acts in Northern Nigeria claim to be inspired by Islamic doctrine. By their nature, such attacks are unexpected, and probably the more reason why they come along with such terrible consequences. Furthermore, several conflicts in Africa, especially political ones, have religious undertones (Akrong 2003, 37).

In spite of the foregoing observations about the negative effects of religion, it would be quite incorrect to suggest, as Dennett does, that the world would be better without religion or religious beliefs. He gives the following reasons:

(a) We are quick to condemn other outrages, but religious passion, genuine or feigned, shields people from the moral judgments of their fellow human beings, judgments to which we should all alike be subject ...

(b) True, you don't have to be religious to be crazy but it helps. Indeed, if you are religious, you don't have to be crazy in the medically certifiable sense in order to do massively crazy things. And - this is the worst of it religious faith can give people a sort of hyperbolic confidence, an utter unconcern about whether they might be making a mistake, that enables acts of inhumanity that would otherwise be unthinkable...

(c) The better is the enemy of the best: religion may make people better, but it is preventing them from being as good as they could be. If only we could transfer all that respect, loyalty and intense devotion from an imaginary being - God - to something real: the wonderful world of goodness we and our ancestors have made, and of which we are the stewards (Dennett 2008, 2; lettered numbering added).

With reference to (a) above, it is perturbing how we, as moral agents, would neglect our moral duties (which include encouraging others to avoid acting immorally), simply because a moral agent is 'passionate' about his or her religion. Besides, Dennett conveniently blames 
religion for people's refusal to perform their duties. Religious passion should not shield people from accounting for their morally-relevant actions.

The fact is that people do commit inhumane actions in the name of religion or with the aid of religion. Most parts of Africa suffered this way in the past through slavery and colonialism. Yet there is a basis for blaming the individuals who exploited religion for this, instead of religion itself. Religion, like science (which Dennett regards as rational), are things which could be used by humans for good or evil. It is therefore not entirely true to suggest as in (b) that faith is bad because it 'can give people a sort of hyperbolic confidence, an utter unconcern about whether they might be making a mistake, that enables acts of inhumanity that would otherwise be unthinkable.' Indeed, there are many practitioners of religion who, by virtue of their faith, are 'concerned about whether they might be mistaken' in whatever they do and are also humane.

Dennett's position in (c) that religion can only make its followers better (but not best) because their contribution to the world (of goodness) is reduced by their commitment to a rather imaginary God is quite mistaken: it presumes that the activities of the followers of all religions are geared toward pleasing God, and therefore the ethics or standards of right and wrong in all religions are determined on the basis of supernatural considerations (God's will). This is not the case with Traditional Akan Religion, where God's will is not cited as the basis for human action. The religion, as mentioned above, aims at enhancing the well-being of humanity in this world. This means that contrary to Dennett's thinking, it is possible to practice religion and orient one's actions and energies toward making better (or even best) 'the wonderful world of goodness we and our ancestors', for many centuries, have invested so much into. In Lord Winston's critique of Dennett, he highlights another position of Dennett's which is quite relevant to the point I am making:

Dennett argues that it is better to live as if there is no God, attempting to make the world a rational and better place ... An atheist will lose nothing if God does not exist - his or her memorial will be good deeds. And if there is a benevolent God, Dennett will find himself judged by the Almighty on his merits, not because of the disbelief he professes (Winston 2008, 3).

The idea that people should live as if there is no God seems to be conditioned upon, first, the conviction that religious belief or practice makes it difficult, if not impossible, to make the world a rational or better place. However, this is not only partial and erroneous, but, more importantly, it disregards the nature of Traditional Akan Religion whose ethics have a human 
rather than a supernaturalistic basis. This religion holds that one does not need God to attempt to make this world a 'rational and better' place. Secondly, the view seems to assume that being an atheist is synonymous with, or predisposes one to, doing good deeds, yet there is no evidence for this.

\section{Reason \& Salvation}

I have so far argued that the rejection of religion and, by implication, Traditional Akan Religion, cannot be maintained on the grounds of irrationality. However, this does not mean that all the problems about natural religion are resolved. From the most unlikely source, another challenge is raised, namely, against the relevance of reason in religion. Some Christian theologians reject natural theology because, to them, reason does not help in any way in the attainment of salvation (Kenny 1992, 3-4). I am aware that this assertion is not made in reference to Traditional Akan Religion. If it was, it would still not have been fatal because aside from my doubts about whether the concept of salvation can be found in Akan religious thought, I have in the foregoing discussion shown how significant and, perhaps, indispensable reason is to Traditional Akan Religion. I am also of the view that the position attributed to the Christian theologians fuels the wrong perception that God - and in some sense, religion - discourages humans from exhibiting their most distinguishing characteristic: rationality. It is as a result of the risks associated with such teaching that Karl Marx's Das Kapital 'ruthlessly' criticized religion some two centuries ago. Although I am not quite sure whether religion could rightly be described as 'the opium of the masses', Marx's attempt and those of many other philosophers to highlight and uphold the importance of reason is nonetheless legitimate. Without the correct exercise of reason, all religions (Akan religion included) are open to intellectual and practical abuse. For example, in the name of religion there might be oppression or killing of humans by fellow humans. However, if these acts can also be committed outside religious contexts, then, just as one cannot, on the basis of such actions, say that nonreligious life is irrational, it would equally be inappropriate to say that (belief in) religion is irrational. Humans ought to be guided by reason in their choices of belief or action, whether the belief or action is religious or not. This means that the failure of an individual who subscribes to a religion to exercise reason would not justify the characterization of the generality of religion as 'irrational'. 


\section{Meaninglessness of Religious Language}

In Traditional African Religion, statements are sometimes attributed to supernatural beings, especially to the deities and the living-dead (Akan nananom nsamanfo). Such statements are of religious and, quite often, practical significance to those who profess the religion. Nevertheless, the meaningfulness and credibility of such statements would be met with such opposition as one would expect with revealed statements of God (held, for example, in Christian thought). These two kinds of statements have in common a source which is metaphysical. But is it possible for a statement attributed to a metaphysical being to be acceptable on rational grounds? Although Traditional African (and for that matter, Akan) Religion is not revealed, the analyses of metaphysical claims by some Western philosophers in connection with revelation have the same implications for Traditional African belief in, say, oracular predictions. There is need, therefore, to look briefly at how the meaning of claims that have metaphysical sources have been dealt with in Western philosophy, taking revelation as an example.

It is no secret that the revealed words or wishes of God are what Christian theologians claim to derive their authority from. Even so, the fear of some philosophers has been that since claims attributed to a supernatural God cannot be tested, it makes, at the very least, objective truth about God's revelations difficult to attain. In the absence of testing, it is assumed, any string of words or array of sounds could be tendered as a piece of revelation, and would be a classic case of Feyerabend's "anything goes". 6 The trouble with any thing so tendered is that it would be frustrating to investigate - if investigating it is possible at all - and would, in some sense, impinge on the reliability of revelation.

This obvious need to avoid frustration seems to make a good case for the philosophical doctrine of empiricism. In line with this doctrine, the reality of the metaphysical was strongly rejected by David Hume (1893, Section IV) and also forcefully so by the Logical Positivists. ${ }^{7}$

\footnotetext{
${ }^{6}$ This does not mean that the idea of "anything goes" expressed in his Against Method has not been applied in some aspects of human life commonly regarded as rational. Taking inspiration from this work of Feyerabend's, for instance, Gjertsen (1989, 153-154) emphasizes the adoption of "anything goes" attitude by scientists.

${ }^{7}$ In the citation above, Hume mentions matters of fact and relations among ideas as the only ways through which we can know. He therefore completely rejects metaphysics. Besides, although at page 4 of his cited work, Kenny identifies Logical Positivism as one of the major obstacles to (natural) religion, I will show why a position such as this appears now to have less traction.
} 
The Pre-War Logical Positivists held that a claim (that is, an entire statement) is meaningful if it is either a priori, or if it refers to a state of affairs which is verifiable, directly or otherwise. However, the alleged meaningfulness of factual statements had been challenged by Wittgenstein. In the Tractatus (Wittgenstein 1951, 79), unlike in some of his later works, Wittgenstein argued that no statement made in relation to language (that is, that which purports to express a relation between language and reality) could be sensible either, because it could not be expressing observable, verifiable facts. However, the Positivists thought that the meaningfulness of statements that were not a priori would create a problem of understanding, unless their verifiability was established (A.J. Ayer's 1946, chapter 1 is an example). ${ }^{8}$ They would then argue that “... anybody who concerns himself with [metaphysical claims] for any purpose except to expose their senselessness is wasting his time" (Whiteley 1959, 245). It would also be consistent with their view to assert that any claim that is not verifiable is meaningless because it has no referent, and that since we do not actually know what such a statement refers to, we cannot tell what to observe in order to confirm or disconfirm it.

Nevertheless, Logical Positivism's over-reliance on the empirical approach of the natural sciences is questionable in some respects. As far back as 1959, Whiteley had made some important observations: that even if the principle of verifiability is accepted, it may not affect metaphysical statements any worse than it would do to some scientific statements because there still are "indirect ways in which a statement may be connected with empirical facts, and may be rendered more or less plausible in their light, without it being possible to deduce any observation statement from it" (Whiteley 1959, 245). If, in spite of the general nature of scientific hypotheses, they are still considered by most, if not all, empiricists as contributing to knowledge, that cannot be because there is any particular observation statement(s) that they necessarily suggest. These generalizations, Whiteley would assert, are recognized by them because they can be used to say other things which experience can refute or confirm. For instance, the claim that "all metals expand when heated" is regarded as empirical and scientifically grounded. Yet there cannot be an observable event that entails "all metals". We can neither be sure that we know "all metals" nor that none will fail to expand in future when mean time, I deal with some further problems perceived to have been generated by the position just attributed to Ayer. 
heated. The general claim, however, becomes empirically significant when specific metals are found and heated up, so that the result would either confirm or disconfirm the claim.

Thus it appears that one need not determine how empirically significant a statement is by asking "What do I have to observe to make sense of this statement?" but, rather, one should address oneself to a question such as "Can this statement be rendered plausible in any way by some empirical facts?" Indeed, Waismann saw through the difficulty of adopting the first question as an approach to determining the cognitive significance of statements. His reason was that "... the living centre of every philosophy is a vision and that it should be judged accordingly". It is, in his words, a "colossal mistake" to concentrate on the words that constitute a metaphysical statement because "A philosophy is there to be lived out. What goes into the word dies, what goes into the work lives." So, given the historical fact that metaphysics has "a certain grandeur in it, a prophetic aspect of the comprehensibility of nature, a bold anticipation of what has been achieved in science at a much later date," quite clearly, "To say that metaphysics is nonsense is nonsense" (Waismann 1968, 38).

Furthermore, given the fact that Moritz Schlick, a logical positivist himself, would come to advocate that the principle of verification accommodate some events whose actual verification is impossible, events which cannot be said to be "the experience of anybody" (Schlick 1949, 169), it would not be out of place to see, in this, the possibility of Schlick adopting an attitude consistent with the line of questioning suggested in the preceding paragraph - as being relaxed and appropriate for any empirical enquiry. Indeed, it is refreshing to realize, also, that the radical posture of A.J. Ayer toward metaphysics in his early writings (as in Ayer 1946) cannot be said of the Logical Positivist's later works. With this, and given the critical positions of Schlick, Whiteley, Waismann and, quite recently, Kenny above on Logical Positivism, it is perhaps an overstatement, if not anachronistic, to cling to the belief that religious or metaphysical language (including that of Traditional African Religion), is problematic merely on the basis of Positivist principles.

\section{Inconsistencies in Religious Beliefs}

In Akan thought, Nyame is believed to be the sole creator of the universe. He is also regarded as good and as a being who dislikes evil. The Akan would say Nyame mpe bōne ("God does not like evil"). He is also described as Otumfoo (the Most Powerful), that is, he is able to do all that He wants. Again, when an Akan wants to express the notion of divine knowledge of 
16 H.M. Majeed

the past, present and future - in contradistinction to finite human knowledge - he/she says Nyame na 'nim ("Only God knows"). God is also believed to seal the destiny of each human being. Yet these beliefs, as I will explain shortly, raise serious philosophical problems.

Religious beliefs - especially belief in God - are very often questioned on the basis of their apparent inconsistency. ${ }^{9}$ The alleged inconsistency is often in connection with the attributes of God in the light of certain features in the universe, such as (i) the presence of evil in creation despite the existence of an all-good God, and (ii) the notion of a foreknowing God who is also non-deterministic. For example, in his analysis of the traditional theological conceptions of divine foreknowledge, the goodness of God and the dissociation of God from evil, Kenny (1992, 121) writes:

If God is to have infallible knowledge of future human actions, then determinism must be true. If God is to escape responsibility for human wickedness, then determinism must be false. Hence, in the notion of God who foresees all sins but is the author of none, there lurks a contradiction.

It is noteworthy that although Traditional Akan Religion is not a revealed religion, Kenny's concerns could relate to it because it also conceives of God as having infallible knowledge, as good, creator of free humans, and author of a world in which there is evil. Kenny's example of inconsistency is therefore relevant to this article because in Traditional Akan Religion, though a natural religion, the problem of evil does exist (Gyekye 1995, 133). Broadly speaking, the view that God is the author of evil in this world is more or less subtly informed by the belief that God is the creator of everything, and is also in the special position of possessing infallible knowledge about His creation. However, with this, two possible implications obtain. First, it could be said that God chose to create the world in such a way that there will be evil in it. Or, what amounts to the same thing, God made evil an option for the human being. Second, it could imply that God is ultimately responsible for the sins of humans.

Not much can be said about the first implication, but the second is particularly incorrect if that is what determinists espouse. Indeed, determinists seem not to deny the second because they refuse to distinguish between acts that are "caused" by God and those that are merely

${ }^{9}$ Consistency is so important an ingredient of rationality that Buchak $(2012,19)$ sees it, along with 'reasonableness', as notions that both epistemic and practical rationality cannot do without. 
"permitted" by God. As Kenny argues, "in a deterministic created universe, the distinction between causing and permitting would have no application to God" (Kenny 1992, 87). To my mind, God's position is just like that of a car manufacturer who, although he/she did not make it with the intention of causing harm, produced a vehicle with the potential to destroy the lives of its occupants through accidents. ${ }^{10}$ Even though there can be some accidents which he might be responsible for, when a wrong judgement on the driver's part results in an accident it would be most inappropriate to pass on the blame to the manufacturer. The manufacturer, therefore, cannot be responsible for all accidents. Similarly, I do not see why God should be responsible for every evil that befalls a person or is performed by a person.

If determinism is true, no person can be considered to be virtuous, because he/she exhibits good character not by any effort of his/her own. It would also mean that no person is vicious, although he/she can act viciously. Nevertheless, these inferences are not valid. The fact that people can be taught or advised to change their evil ways, and the fact that those who were initially seen to be virtuous can, upon the desire to gain certain advantages in life, engage in such immoral actions as degrading or polluting the environment, committing genocide and exploiting weak people, point more to the activities of free, deliberative persons than to individuals whose actions are determined by God. It appears, then, that for a person to choose one option as the most effective means to attain his/her ends, he/she might have already considered other options and adjudged himself/herself free to do the choosing.

However, Kenny sets out from the premise that God's knowledge of future actions brings those actions into being, or, at least, makes them ineluctable. ${ }^{11}$ I disagree. God's foreknowledge is knowledge of everything in advance all right, but this does not necessarily lead to the conclusion that His knowledge of something makes it happen. It may as well be that it is because the event or action in question will come to pass that God knows it as such. To be eternal is not to be foreknowing, although one can be both. However, foreknowledge

\footnotetext{
${ }^{10} \mathrm{I}$ am not in any way equating the person to God (being a creation of God himself/herself, and with numerous inadequacies); but I am saying that, as moral agents, human beings are affected almost the same way by the creations of these two creators.

${ }^{11}$ Find the connection between the views of these philosophers in Kenny. There, specifically in Kenny 1992, 7 , it is also evident that having the wrong notion that divine foreknowledge implied determinism, Boethius attempted to make God's knowledge accommodative of human free will with the puzzling argument that “... because God's eternal life was simultaneous with the whole of history, God's knowledge was not knowledge in advance."
} 
consists in perceiving and understanding future happenings as they are. Given this, God's foreknowledge of future human actions could be explained as Him perceiving, without necessarily 'dictating', how a person is going to act in future. Now, if that knowledge is considered infallible, it is probably because God perceives clearly. This way, free will becomes conceivable in a world whose author has foreknowledge. Consequently, there is no reason for God to expect any surprises about His perceptions regarding future human actions in order for humans to be classified as free. The significance of all this is that one can hope and rationally believe that what one chooses to do in this world is what God foreknows.

A distinction needs to be made, however, between God's foreknowledge and predestination. While the former does not commit one to the notion of determinism, the latter - if it is a true notion - seems more likely to present a challenge to the concept of human free will. Predestination, potentially, has the negative effect that it may lead a person to a state of resigned acceptance of his/her circumstance and, worse still, be indifferent to real life options which he/she could have otherwise taken advantage of. Nevertheless, to the wise person, the truth of predestination will not be a hindrance to his/her efforts at bettering his/her present condition, and will not reduce or take away his hopes for the future; neither will it discourage him from working toward a desired future. Indeed, there is no inconsistency in believing that one's destiny is fixed and trying to lead a better life here on earth.

I must now endeavour to consider the possibility of Nyame's (God's) intervention in human affairs. One may ask: if Nyame knows something evil will happen or will be done, why does He not prevent it? In terms of the moral actions of the human being, Akan thinkers suggest that Nyame created him/her free and rational. Nyame gave the human being fa'hodie (freedom). This implies that in Akan ethics, the human being is not deemed to act under compulsion (nhyesoō) from either Nyame or other humans. It can therefore be seen that in Akan religious thought, human choices are not determined. For this reason, Nyame cannot be expected to limit the choices of humans even if they are immoral. Nyame does not only want good deeds from humans, but also wants the human being to be free. In terms of natural disasters that bring pain (evil) to the human being, no clear reasons are given as to why Nyame does not prevent them from happening. Yet this is not a reason to consider the whole gamut of Akan religious beliefs to be irrational. To do so would be way too extreme and inappropriate, for not even science, the so-called arbiter of rationality, can justify all its basic beliefs. 


\section{Conclusion}

In an attempt to examine some concepts of religion, and to determine whether religion could be of any rational significance to humanity, some Western scholars have come to the conclusion that religion is completely irrational. People are thus urged to break free from the prescriptions of religion which, it is often suggested, are sometimes unhelpful. While acknowledging that many undesirable acts could be undertaken in the name of religion, this article has suggested a possible de-linking of such acts from religion in some contexts. It has also examined the rejection of religion on the basis of the alleged irrationality of religion. It has argued that part of the problem has to do with misconceptions surrounding religious beliefs, and has accordingly attempted to show that it is possible to deal adequately with the confusion and inconsistencies that characterize people's thoughts about basic religious concepts (such as God, good and evil) without necessarily rejecting religion. Although it is not quite clear why a revealed religion cannot have a rational basis, some scholars think that this is the case. Nevertheless, this article has argued that even assuming that their judgment is correct, their attempt to tag all religions 'irrational', as if no religion is a complete creation of humankind, is erroneous. Akan religion, particularly, has been presented as being a purely human creation.

Traditional Akan Religion, therefore, cannot be squeezed out of the domain of natural religion, neither does it lend itself to irrationality, contrary to what Dennett, Horton and others would want us to believe about the nature of all religions. Furthermore, very few philosophers these days regard metaphysical issues as beyond investigation and meaningless. Metaphysical claims are not necessarily mysterious: the metaphysical is mysterious only to the extent of its being intangible, but not in the sense that it is so obscure as to be rationally inexplicable. I am not in any way suggesting that every metaphysical question is tractable, but there is need to guard against any watering down of the significance of metaphysics merely on the ground that it is not empirically verifiable.

Whether a metaphysical entity actually exists or not, we should be able to determine if what is said about it makes use of basic principles that govern philosophical reflection. For example, one would not commit any philosophical crime if one affirmed that something cannot be said and denied of an entity at the same time, whether or not that entity exists. So, without knowing everything, a philosopher can talk about anything. This is mainly because 
20 H.M. Majeed

what matters in philosophy is not only 'what' is said or talked about, but also 'how' it is said or how the talking is done. 


\section{References}

Abioje, Pius O. 2007. "Divine Revelation in African Religion among the Yoruba and in Christianity". Legon Journal of the Humanities, Vol. XVIII, pp. 145-158.

Akrong, Abraham. 2003. "African Traditional Religion and Development: Clash of Two Worlds of Discourse and Values". Trinity Journal of Church and Theology, Vol. XIII No. 3, pp. 37-49.

Ayer, Alfred J. 1946. Language, Truth and Logic. Harmondsworth, Middlesex: Penguin.

Buchak, Lara. 2012. "Can it be Rational to Have Faith?" Jake Chandler and Victoria S. Harrison eds. Probability in the Philosophy of Religion. Oxford: Oxford University Press. http://philpapers.org/rec/BUCCIB

Dennett, Daniel. 2008. "Is Religion a Threat to Rationality and Science?" Public Debate between Daniel Dennett and Lord Winston held on April 22, 2008. http://www.theguardian.com/education/2008/apr/22/highereducation.uk5

Dawkins, Richard. 2007. The God Delusion Black Swan Edition. London: Transworld Publishers.

Feyerabend, Paul. 1993. Against Method, Third ed. London: Verso Books.

Gjertsen, Derek. 1989. Science and Philosophy: Past and Present. London: Penguin.

Gyekye, Kwame. 1995. An Essay on African Philosophical Thought: The Akan Conceptual Scheme, Revised ed. Philadelphia: Temple University Press.

--. 1996. African Cultural Values: An Introduction. Accra: Sankofa.

Horton, Robin. 1960. “A Definition of Religion, and Its Uses”. Journal of the Royal Anthropological Institute of Great Britain and Ireland, Vol. 90 No. 2, pp. 201-226.

Hume, David. 1893. An Enquiry Concerning Human Understanding. Selby-Bigge, L.A. ed. Oxford: Clarendon Press.

Idowu, B.E. 1962. Olodumare: God in Yoruba Belief. London: Longman.

Jarvie,I.C. and J. Agassi. 1977. "The Problem of the Rationality of Magic". Wilson, Bryan R. ed. Rationality. Oxford: Basil Blackwell, pp. 172-193.

Kenny, Anthony. 1992. The God of the Philosophers. Oxford: Oxford University Press.

Mbiti, John S. 1997. African Religions and Philosophy, $2^{\text {nd }}$ revised and enlarged ed. Oxford: Heinemann.

Opoku, Asare K. 1978. West African Traditional Religion. Accra: F.E. P. International Private Limited.

Quarcoopome, T.N.O. 1987. West African Traditional Religion. Ibadan: African Universities Press.

Schlick, Moritz. 1949. "Meaning and Verification". Feigl, H. and W. Sellars eds. Readings in Philosophical Analysis. New York: Appleton Century-Crafts, pp. 146-170. 
Soyinka, Wole. 2004. "The Burden of Memory, the Muse of Forgiveness". Scheper-Hughes, Nancy and Phillipe I. Bourgois eds. Violence in War and Peace: An Anthology. Malden: Blackwell.

Waismann, Friedrich. 1968. How I See Philosophy. London: St. Martins Press.

Whiteley, C.H. 1959. "Metaphysics and Science". The Philosophical Quarterly, Vol. 9 No. 36, pp. 244-249.

Winston, Robert. 2008. “Is Religion a Threat to Rationality and Science?” Public Debate between Daniel Dennett and Lord Robert Winston held on April 22, 2008, http://www.theguardian.com/education/2008/apr/22/highereducation.uk5

Wiredu, Kwasi. 1980. Philosophy and an African Culture. Cambridge: Cambridge University Press.

Wittgenstein, Ludwig. 1951. Tractatus Logico-Philosophicus (with an introduction by Bertrand Russell). London: Routledge \& Kegan Paul.

--. 1966. "Lectures on Religious Belief". Cyril Barrett ed. Lectures and Conversations on Aesthetics, Psychology and Religious Belief. Oxford: Basil Blackwell, pp. 53-72. http://philpapers.org/rec/WITLC 